\title{
Use of synthetic aperture radar for recognition of Coastal Geomorphological Features, land-use assessment and shoreline changes in Bragança coast, Pará, Northern Brazil
}

\author{
PEDRO W.M. SOUZA-FILHO ${ }^{1}$ and WALDIR R. PARADELLA ${ }^{2}$ \\ ${ }^{1}$ Laboratório de Análise de Imagens do Trópico Úmido, Centro de Geociências, UFPA \\ Cx. Postal 1611, 66075-110 Belém, PA, Brasil \\ ${ }^{2}$ Instituto Nacional de Pesquisas Espaciais, São José dos Campos \\ Cx. Postal 515, 12227-010 São Paulo, SP, Brasil \\ Manuscript received on September 9, 2002; accepted for publication on March 7, 2003; \\ presented by RoBerto DALL'AGNOL
}

\begin{abstract}
Synthetic Aperture Radar (SAR) images are being used more extensively than ever before for geoscience applications in the moist tropics. In this investigation, a RADARSAT1-1 C-HH SAR image acquired in 1998 was used for coastal mapping and land-cover assessment in the Bragança area, in the northern Brazil. The airborne GEMS $1000 \mathrm{X}-\mathrm{HH}$ radar image acquired in 1972 during the RADAM Project was also used for evaluating coastal changes occurring over the last three decades. The research has confirmed the usefulness of RADARSAT-1 image for geomorphological mapping and land-cover assessment, particularly in macrotidal mangrove coasts. It was possible to map mangroves, salt marshes, chenier sand ridges, dunes, barrier-beach ridges, shallow water morphologies and different forms of land-use. Furthermore, a new method to estimate shoreline changes based on the superimposition of vectors extracted from both sources of SAR data has indicated that the shoreline has been subjected to severe coastal erosion responsible for retreat of $32 \mathrm{~km}^{2}$ and accretion of $20 \mathrm{~km}^{2}$, resulting in a mangrove land loss of almost $12 \mathrm{~km}^{2}$. In an application perspective, orbital and airborne SAR data proved to be a fundamental source of information for both geomorphological mapping and monitoring coastal changes in moist tropical environments.
\end{abstract}

Key words: geomorphology, coastal changes, remote sensing, mangrove, Amazon.

\section{INTRODUCTION}

The landforms along the Bragança macrotidal mangrove coast of Pará State (northern Brazil) are complex and dynamic in nature. Their developments are largely controlled by the interplay of various spatial and temporal factors including wind, waves, tides and currents, coupled with geology, vegetation, climate and time. The coastal processes of erosion, transport and deposition and their link to

Correspondence to: Pedro W.M. Souza Filho

E-mail: walfir@ufpa.br flooding and relative sea level changes have continuously modified the coastal environment. Thus, the understanding of the landform developments and an in-depth knowledge of the spatial and temporal changes are critical to characterize the coastal zone, aiming at the protection of this sensitive tropical environment. Recent studies have addressed the use of orbital Synthetic Aperture Radar (SAR) as an ideal data source for flooding, wetland and hydrological studies in the Amazon (Novo et al. 1998, Forsberg et al. 2000, Proysi et al. 2000, Costa et 
al. 2002, Rosenqvist et al. 2002). The cloud penetration ability and the day/night imaging capabilities allow valuable information to be extracted when data acquired by conventional optical remote sensing imagery are restricted. The difference of SAR return from land versus water is primarily a function of contrast of dielectric properties and surface roughness, providing a striking interface which also facilitates coastal delineation and related mapping studies (MacDonald et al. 1971, Lee and Jurkevich 1990, Ellis and Richmond 1991).

Geomorphologically, the Amazon coastal zone is poorly mapped. The Bragança coastal area, which is located on the easternmost border of the Amazon Region, is part of a muddy coast, which constitutes one of the largest macrotidal mangrove coast of the world, with almost $8,900 \mathrm{~km}^{2}$ (Kjerfve et al. 2002). The RADAM Project, in the beginning of the 70's, carried out the first regional airborne SAR mapping in the area. With the side viewing geometry and using a high microwave frequency $(\mathrm{X}-\mathrm{HH})$, images from the Goodyear Mapping System (GEMS 1000) were extensively used as an operational tool for regional mapping in the coastal Amazon environments (Projeto RADAM 1973).

With the advent of SAR-satellite imageries, several studies focussed on the use of orbital SAR data for coastal applications in the moist tropics (Singhroy 1996, Barbosa et al. 1999, Kushwaha et al. 2000, Proysi et al. 2000). This paper addresses the importance of using old and new SAR data acquired from GEMS 1000 and RADARSAT1 , respectively, for tropical coastal studies in the Amazon coastal zone focussing on geomorphological mapping, erosional and land-cover assessments.

\section{STUDY AREA}

The study area is located on the northeast of Pará State, approximately at $1^{\circ} \mathrm{S}$ and $46^{\circ} \mathrm{W}$ (Figure 1). A continuous mangrove belt of around $20 \mathrm{~km}$ wide fringes the shoreline with elevation from 1 up to 2 m above mean tide level (Cohen et al. 2000). A wet season from December to May and a dry season from June to November mark the climate (Martorano et al.
1993). Trade winds blow from northeast throughout the year and strong winds characterize the dry season (Silva 2001). The average annual rainfall reaches 2,500 $\mathrm{mm}$ and the mean tidal range is around $5 \mathrm{~m}$ on a semi-diurnal cycle (DHN 2000). Thus, large areas of the low lands are flooded during spring tides due to both rainfalls with high runoff rates and tidal effects. On one hand, strong tidal currents from east to west and waves $1.5 \mathrm{~m}$ high are responsible for the erosion of mangroves along the coast, estuaries and bays, where lines of fallen mangrove trees mark the eroded sites. On the other hand, new mangrove fringes are prograding seaward in response to muddy sedimentation (Souza Filho et al. 2003).

The Bragança area is inserted within the Bragança-Viseu Coastal Basin, with Quaternary deposits controlled by the geometry and paleotopography of the Basin (Souza Filho 2000a). The Holocene sedimentary evolution of this coastal plain began at 5,100 years B.P, when the relative sea level reached its maximum. From 5,100 years B.P on, the sedimentary evolution is a result of coastline progradation with development of a mangrove system, intercalated with short-term retrogradation events responsible for coastal erosion and deposition of old and recent barrier dune-beach ridges (Souza Filho and El-Robrini 1998, Behling et al. 2001).

The Bragança coastal plain is extremely irregular and jagged with a low gradient coast. Topographically, the study site is a low relief terrain. The tidal flat, including a mangrove system, is characterized by local slopes varying around 1:3000 $(0.033 \%)$ with topographic breaks dissected by creeks. Salt marshes constitute the highest areas of the coastal plain with a topographic relief reaching $3 \mathrm{~m}$ above the mean tidal level, while intertidal mangroves are related to relief variations from 2 to $2.6 \mathrm{~m}$. Supratidal mangroves are associated with altitude variations from 2.6 to $2.8 \mathrm{~m}$ above the mean tidal level. Consequently, salt marshes are inundated only 28 days/yr., while mangroves remained flooded from 51 days/yr. (supratidal mangrove) to 233 days/yr. (intertidal mangrove) (Cohen et al. 2000).

The original vegetation of the coastal plateaus 


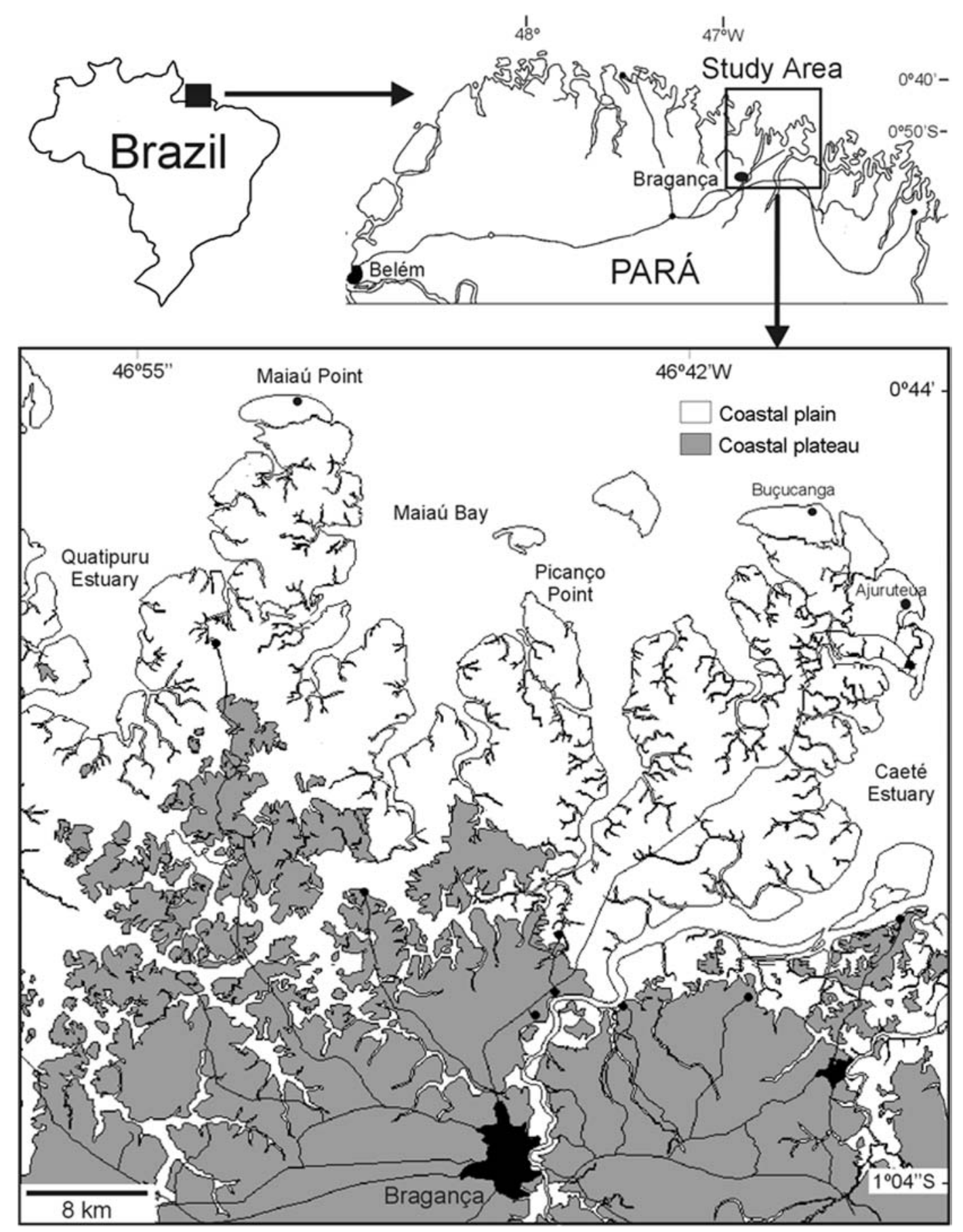

Fig. 1 - Location map and geomorphological compartments of the Bragança coastal plain.

is typical of the tropical rain forest. This vegetation cover has been affected by anthropogenic activities, such as agriculture and human settlements. Man- grove forest is found on the tidal flat, grasses occur along the marshes and arbustive vegetation occupies the chenier sand ridges, dunes and backshore 
zone of the barrier-beach ridges (Souza Filho and El-Robrini 1996).

\section{DATA SET AND IMAGE PROCESSING}

The investigation was based on airborne and orbital SAR data. The airborne imaging radar was a SAR built by Goodyear Aerospace Corporation (GEMS 1000), and operating in the X-HH band $(9,600 \mathrm{MHz})$, with nominal ground resolution around $16 \mathrm{~m}$. The north-south airborne flights, with a westward looking direction, were carried out along 1972 dry season as part of the RADAM Project (Moreira 1973). The orbital SAR corresponded to C-HH $(5.3 \mathrm{GHz})$ band imagery related to the RADARSAT-1 Fine Mode with a 10-meter nominal ground resolution. Both SAR images were acquired at high tide conditions.

The SAR's ability to delineate the land/water boundary and to map geomorphological features and flooded vegetation is largely dependent on the incident angle (Leconte and Pultz 1991, Lewis et al. 1998). In low relief environments, small incidence angles (10 to 25 degrees from vertical) will produce the maximum relief enhancement, but larger incidence angles (25 to 59 degrees) will also result in acceptable terrain rendition by increasing the terrain textural contrasts (Singhroy and SaintJean 1999). Normally, the coastline delineation is best achieved using large incidence angle (25-59 degrees) due to the high contrast in radar return from land (surface and volume scattering mechanisms) and water (specular reflection mechanism). However, surface variations and flooded vegetation are best-characterized using small incidence angle (2540 degrees). In other to satisfy both requirements the Fine Mode 1 of RADARSAT- 1 data was selected and the image was acquired in 1998 on a descending pass (west-looking) during the dry season, as part of the GLOBESAR-2 Program (Paradella et al. 1997). Details of the SAR data used in the investigation are presented in the Table I.

Digital image processing was carried out using EASI-PACE software (PCI 1999). Previous studies in the Amazon have shown that some procedures need to be applied to SAR due to the unique radar viewing geometry, causing specific induced-relief geometric distortions and the presence of speckle (Paradella et al. 1998, 2000). Thus, the orbital data was initially scaled from 16 to 8 bits. Due to the fact that the area is related to an extremely low topographic relief, the RADARSAT-1 image was geometrically corrected through an ortho-rectification scheme assuming a flat terrain model. Fifty-six features on the image were selected on the terrain and the correspondent geographical information was acquired during a GPS (Global Position System) field campaign. The fifty-six GCP's (Ground Control Points) were used as input for the geometric modeling. The statistics of the ortho-rectification indicated a total accuracy error, as reflected by the RMSE (Root Mean Square Error) residuals, around 12 meters and this value was used as the pixel size for the geo-referenced scene.

In order to reduce speckle, one of the main problems when dealing with SAR digital data (Lopes et al. 1990), the adaptive enhanced-Frost filter $(3 \times 3$ window $)$ was used during the interpolation phase of the ortho-rectification. The main steps of the digital image processing are presented in the flow chart of Figure 2. Finally, the image was linearly stretched in order to enhance contrasts between the coastal features, and visually interpreted based on conventional photointerpretation keys (tone, texture, pattern, form, size and context). Panchromatic air-photos were also used as ancillary data during the interpretation phase and ground truth data were acquired during the field work.

The original GEMS 1000 strips were scanned, mosaiced and digitally rectified to a common UTM coordinates. Fifty-one GCPs input into a first order polynomial transformation and the total accuracy indicated by the RMSE for the geometric correction was around 16 meters. The final airborne image was generated based on a cubic convolution interpolation and 12-meters pixel spacing to allow comparison with the orbital SAR data. In order to extract the shoreline position in 1972, the airborne image was analyzed and the boundary between emerging 


\section{TABLE I}

Characteristics of the SAR data.

\begin{tabular}{c|c|c|c|c|c|c}
\hline Platform & Sensor & $\begin{array}{c}\text { Acquisition } \\
\text { date }\end{array}$ & $\begin{array}{c}\text { Angle of } \\
\text { incidence }\end{array}$ & $\begin{array}{c}\text { Spatial } \\
\text { resolution }(\mathrm{m})\end{array}$ & $\begin{array}{c}\text { Image } \\
\text { format }\end{array}$ & $\begin{array}{c}\text { Azimuth } \\
\text { direction }\end{array}$ \\
\hline RADARSAT & Fine Beam Mode 1 & September, & $37-40^{\circ}$ & $9,1 \times 8,4$ & 16 -bits & $282^{\circ}$ \\
Aircraft & GEMS 1000 & 1998,1972 & $45-77^{\circ}$ & $16 \times 16$ & Analogic & $270^{\circ}$ \\
\hline
\end{tabular}

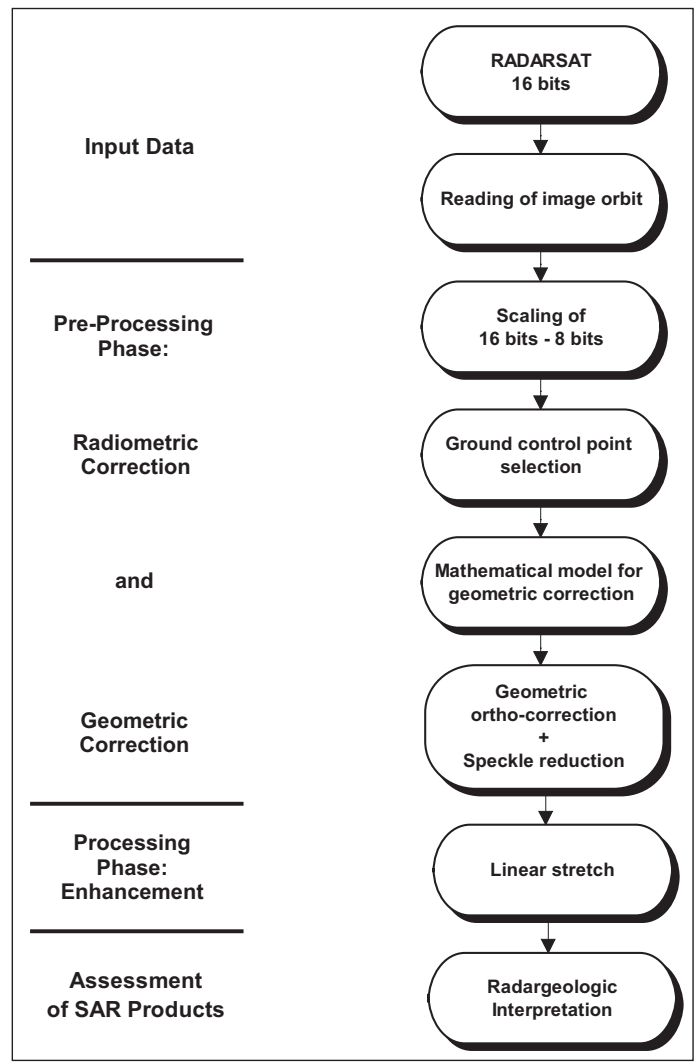

Fig. 2 - Flow chart with the main steps of RADARSAT image processing.

coastal areas and coastal water was automatically extracted. The resulting land-water limit line was converted from raster to vector and superimposed to the RADARSAT-1 image allowing an effective measurement of the spatial coastline changes during the 26-years period of the two SAR imageries.

\section{RESULTS AND DISCUSSION}

\subsection{Coastal Geomorphological Mapping}

Geoscientists make use of the same clues for radar analysis that are applied for visual interpretation of aerial photographs and the identification of forms and the interpretation of processes rely mainly on image tonal and textural attributes. Texture describes the arrangement of spatial patterns or variation in tone within an area of the image. Based on visual interpretation of the RADARSAT-1 image, the following six prominent geomorphological coastal features were detected and examined in detail. In addition, the orbital SAR data was also evaluated to identify coastal environment features and shallow water morphology (Figures 3 and 4).

Mangroves - The use of SAR imagery for the delineation and mapping of mangrove forests along tropical coasts is normally facilitate due to a high contrast with water. A smooth body of water is a specular reflector, reflecting most of the incident microwave energy away from the sensor (very dark grey tones). Areas not covered by water are diffuse scatters, returning a larger proportion of incident microwave energy to the antenna (intermediate tones). In the case of flooded vegetated areas, the radar signal, which reaches the water, is reflected away and interacts with trunks and vice versa, forming corner reflectors, thus resulting in a larger amount of the signal being returned to the sensor (bright tones). The mangrove ecosystem in the area has a width of about $20 \mathrm{~km}$ and is densely covered by forests located from the high spring tide to the mean tidal level. The RADARSAT-1 image interpretation has indicated that intertidal mangroves (trees $\sim 20 \mathrm{~m}$ 
height) show microwave responses controlled by the vegetation cover (volume scattering) and by water/trunk interaction (double-bounce effects); this is responsible for a very rough image texture and lightgray tones allowing their discrimination (Figure 3). The supratidal mangrove presents a similar behavior, however mangrove trees are smaller and spaced, presenting a reduced double-bounce effects. As expected, the image texture related to this target is finer and dark-grayish (Figure 3).

Salt marshes - The inner (hinterland) and outer (peninsula) marshes are situated in the supratidal zone and are mainly flooded during equinoctial tides, with sedimentation marked by mud deposition carried from tidal fluxes along creeks (Souza Filho and El-Robrini 1996). The RADARSAT-1 image clearly outlines the marshes. The inner marsh, completely flooded in the rainy season, is related to a very dark tone in the SAR image due to a quasi-specular response when the radar signal interacts with water and aquatic vegetation (Figure 3). The inner marsh also presents areas dominated by a grass-coverage; hence the microwave responses in the image are associated to a slightly rougher surface with lighter gray tones (Figure 3). Finally, the outer marsh presents the similar image pattern to the inner one, indicating the same scattering mechanism (Figure 3).

Chenier sand ridges - These landforms are essentially old dune-beach ridges with associated washover fans. They have a well-characterized topographic geometry given by linear and curved forms with boundaries marked by prograding tidal mudflats (Souza Filho and El-Robrini 2000). The chenier sand ridges are related to well-defined RADARSAT-1 patterns expressed as striped smooth surfaces with dark tones (Figure 3). These backscattered responses seem to be related to a morphosedimentary control given by the presence of dry sandy sediments of old dune-beach ridges and washover fans which are responsible for a low moisture content and a lower microwave signal return. Since the intertidal mangroves around the cheniers are related to microwave responses controlled by double-bounce mechanisms (light gray tone), the image contrast favors the discrimination between them (Souza Filho and Paradella 2002).

Barrier-dune beach ridges, tidal sandflats and ebb-tidal deltas - These clastic sedimentary coastal environments are the most dynamic of the study area and deserve special attention because they represent one of the most sensitive indicators of coastal changes and processes. Coastal sand dunes consist of sandy sediments of tidal shoals and beaches reworked by the wind and are currently migrating landward over the mangrove deposits in the intertidal mudflats. Transverse and pyramidal dunes are composed of well-sorted and very fine quartz sands and are partially or completely covered by vegetation. The beach ridges extend from the low spring tidal levels to coastal dune-beach scarps that represent the higher spring tidal level in the intertidal beach. The beaches have a linear and elongated form along an east-west direction, with curved spits in the longshore sediment transport direction (Souza Filho et al. 2003). The beach ridges play a key role in the protection of the backward areas, which are characterized by the presence of slack water muddy sediments, salt grasses, and mangrove trees. Tidal sandflats occur along the coast between mean tidal and low spring tidal levels. Sandy tidal shoals with abundant ripples, megaripple marks, and sand waves exposed at low tide are typical representatives of this unit. Ebb deltas extend seaward from tidal creeks in the form of large tidal deltas and are related to shallow waters during high tides.

In the RADARSAT-1 scene, these coastal features are shown as smooth and very dark image patterns close to shoreline (Figure 3) due to specular scattering mechanism of the microwave radiation by the water. As a consequence, the landforms discrimination are poor and it will be solely recognized at low tide when they become exposed.

Shallow water morphology - Submerse sandy banks and estuarine tidal channel have been previously mapped from the digital integration of orbital optical and SAR data (Souza Filho and Paradella 2002). Very often, underwater morphology can be 

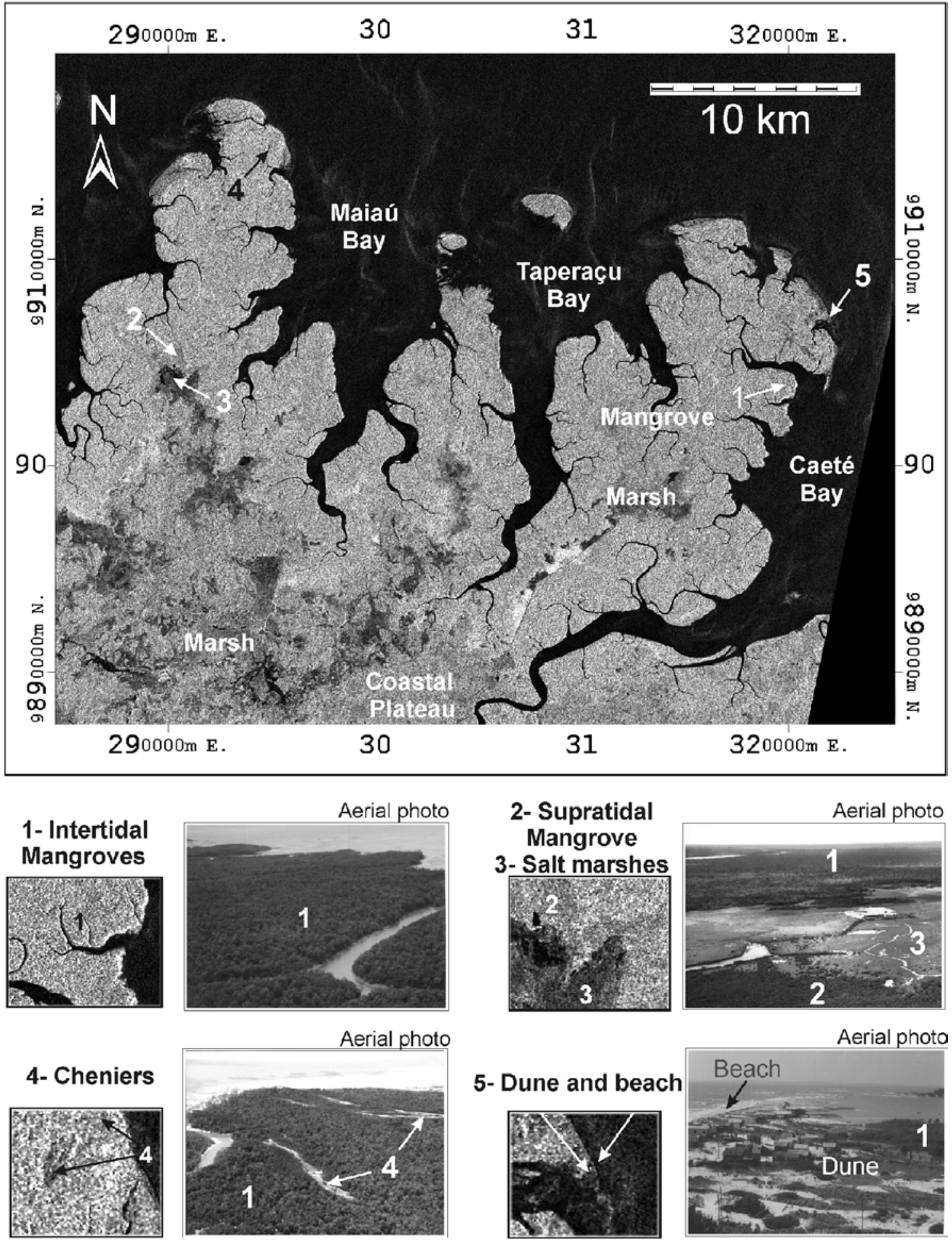

Fig. 3 - Detailed coastal geomorphology of Bragança plain from RADARSAT-1. 


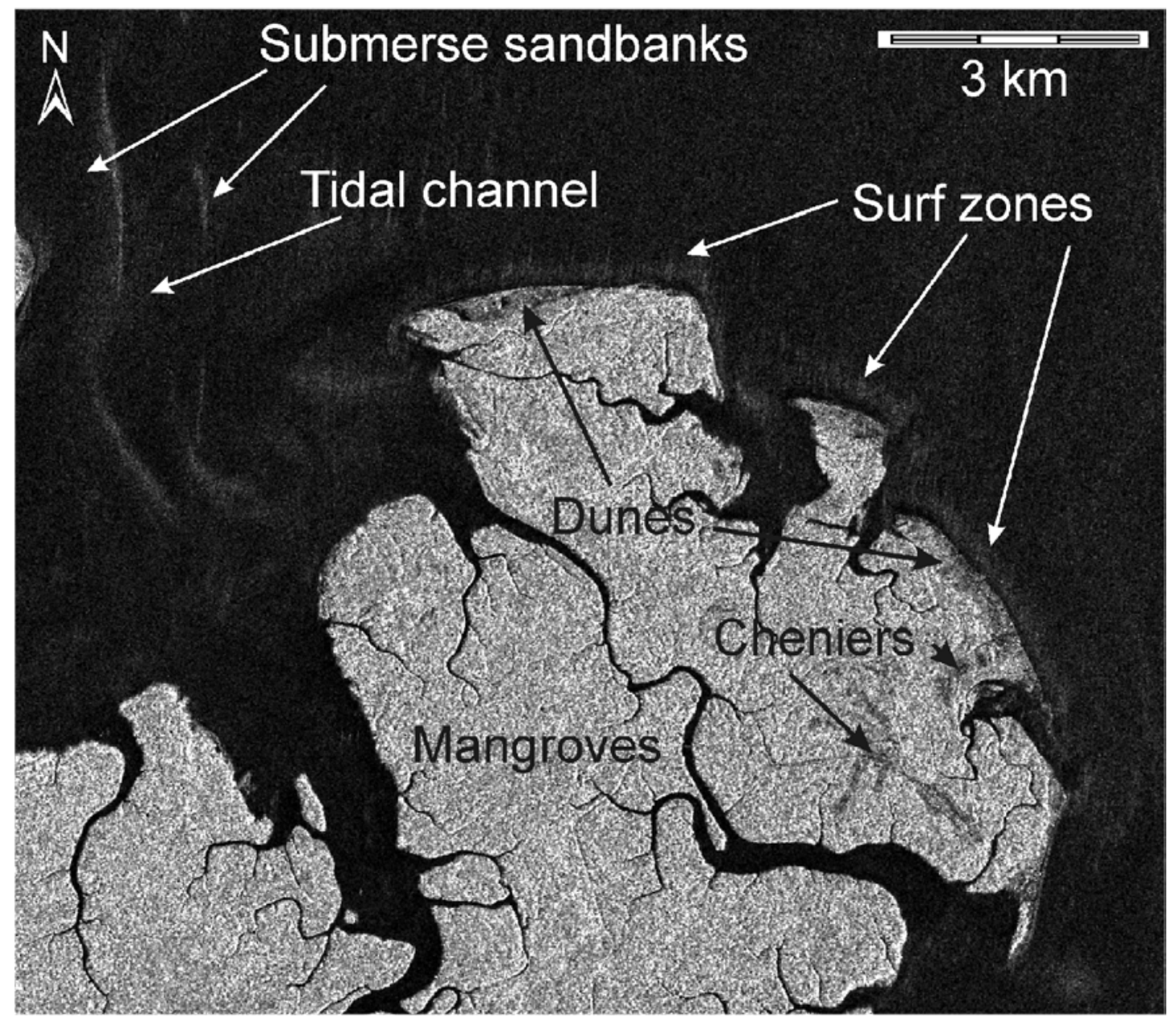

Fig. 4 - Shallow water morphology from RADARSAT-1.

inferred from radar responses of ocean surficial currents and corresponding modulations of the shorter gravity-capillary waves (Johannessen 2000). However, stronger winds tend to produce larger waves and more rippling on the ocean surface with more intense backscatter (lighter tones), which can cause difficulties on the detection of the underwater morphology. On the other hand, the detection of surf zones is normally possible due to the typical surface roughness of breaking surf and multiple reflections from the bubbles (Lewis et al. 1998). These SAR typical characteristics have allowed the mapping of wave fronts in the surf zone, the analysis of the tidal current interactions with bottom features and to lo- cate submerse sandy banks (Figure 4).

Table II summarizes our assessment of the RADARSAT-1 performance for coastal environment mapping for the Bragança area.

\subsection{Mapping of Coastal Land Cover}

The Bragança Coastal Plain has suffered fast and dramatic changes in its landscape. The anthropogenic impacts are basically related to the opening of roads over the mangroves to access the beaches. This process of unplanned coastal occupation has brought damage to the environment, mainly related the disposal of solid wastes along the beaches and groundwater contamination (Souza Filho 2001). 


\section{TABLE II}

Interpretation of RADARSAT-1 image for coastal geomorphological mapping.

\begin{tabular}{|c|c|}
\hline Coastal geological features and land-cover & SAR image interpretation results \\
\hline \multicolumn{2}{|l|}{ A. Coastal environments } \\
\hline Mangrove & $\begin{array}{l}\text { - Coastal areas dominated by forest with average } \\
\text { trees of } 20 \mathrm{~m} \text { high. Mangroves are associated } \\
\text { with rough surface and medium-light tones } \\
\text { (double-bounce). }\end{array}$ \\
\hline Salt marsh & $\begin{array}{l}\text { - Coastal low-lying and water logged terrain } \\
\text { covered by grasses. Slightly rough surface and } \\
\text { dark tones on the SAR image. }\end{array}$ \\
\hline Chenier sand ridge & $\begin{array}{l}\text { - Linear features with up to } 4 \mathrm{~m} \text { high covered by } \\
\text { arbustive vegetation. It is bounded by } \\
\text { mangrove forest and presents rough surface } \\
\text { and medium tones. }\end{array}$ \\
\hline Coastal dunes & $\begin{array}{l}\text { - Linear features up to } 6 \mathrm{~m} \text { high covered by } \\
\text { arbustive vegetation. Slightly rough surface and } \\
\text { dark tones on the SAR image. }\end{array}$ \\
\hline Barrier-beach ridge & $\begin{array}{l}\text { - Linear and flat features in the intertidal zone } \\
\text { without vegetation. Smooth surface and very } \\
\text { dark gray tones on the SAR texture. }\end{array}$ \\
\hline Shallow water morphology & $\begin{array}{l}\text { - Smooth surface with very dark tones intercalated } \\
\text { with light tones defined by shorter gravity- } \\
\text { capillary waves. }\end{array}$ \\
\hline \multicolumn{2}{|l|}{ B. Erosional settings } \\
\hline Coastal forms & $\begin{array}{l}\text { - From } 500 \text { to } 1000 \mathrm{~m} \text { of erosional forms mainly } \\
\text { identified in the open coast as curved shoreline. }\end{array}$ \\
\hline Estuarine forms & - From 30 to 400 m of straight erosional forms. \\
\hline \multicolumn{2}{|l|}{ C. Depositional forms } \\
\hline Mangrove progradation & $\begin{array}{l}\text { - Coastal prograding areas covered by young } \\
\text { mangrove forest with until } 1000 \mathrm{~km} \text { of shoreline } \\
\text { accretion. Rough texture and light gray tones on } \\
\text { the SAR image. }\end{array}$ \\
\hline \multicolumn{2}{|l|}{ D. Land cover } \\
\hline Regenerated mangrove & $\begin{array}{l}\text { - Coastal mangrove forest deforested and now } \\
\text { subject to regenerative process. Rough texture } \\
\text { and highlight tones due to corner reflection. }\end{array}$ \\
\hline Deforested mangrove & $\begin{array}{l}\text { - Muddy soil exposed with smooth surface and } \\
\text { very dark gray tones. }\end{array}$ \\
\hline
\end{tabular}

Along the Bragança-Ajuruteua road, areas have been detected where the mangrove ecosystems are completely deforested or under regeneration.

The interpretation of the RADARSAT-1 image has allowed the mapping of land cover changes. Roads are expressed as flat and linear features bounded by mangrove forest. These areas are depicted as smooth surfaces with characteristic very 
dark striped patterns. Dark areas, resulting of specular scattering, are observed within the deforested mangrove and indicate flooding of muddy sediments by high spring tides (Figure 5). The natural regenerated mangrove sites present sparse and short vegetation distributed over the flat muddy morphology. These factors cause radar/surface interaction to be controlled by "corner reflector" mechanisms, which are a result of high radar returns. Thus, the regenerated mangrove site shows a rough texture with high light gray tones (Figure 5). Note that the presence of an artificial lake, caused by a tidal creek damping by the road, can also be seen in this figure.

\subsection{Spatial and Temporal Analysis of Shoreline Change}

A number of potential shoreline datum or geomorphic features can be used to monitor historical shoreline changes. However, in most situations, the high water line, represented in the study site by the spring high tide level (SHTL), has been demonstrated to be the best indicator of the land-water interface for historical shoreline comparison study (Crowell et al. 1991). Hence, both airborne GEMS-1000 and RADARSAT-1 images were acquired at same high tide condition. The SHTL delineates the landward extent of the last high tide, hence it is easily recognizable in the field and it can usually be detected from airborne and spaceborne remotely sensed data. The landward extent is represented by mangrove forest, which is easily discernible on SAR imageries, and is one of the best geoindicators for evaluating shoreline changes associated with erosional and depositional processes in muddy coasts (Souza Filho 2000b).

The changes in shoreline position for the Bragança area were measured between 1972 and 1998 using information provided from the airborne GEMS and the spaceborne RADARSAT-1 Fine images. The accuracy of the shoreline position for the Bragança area was estimated from the RMSE (root mean square error) of the geometric modeling for both images, i. e., $16 \mathrm{~m}$ for the GEMS image and $12 \mathrm{~m}$ for the RADARSAT-1 Fine image. When considering the errors of both data altogether, the maximum linear and quadratic error for the shoreline position changes were estimated at \pm 28 meters and $400 \mathrm{~m}^{2}$, respectively.

The impact of the natural dynamics at Bragança Coastal Plain produced fast and dramatic changes in the shoreline position during the last three decades. Critical observations of large-scale coastal evolution from SAR imageries provided clues to the natural history. The comparison between 1972 and 1998 showed that the shoreline has been subjected to severe erosion. Figure 6 shows the general results obtained from shoreline analysis from 1998 RADARSAT-1 and 1972 GEMS 1000 data. During this period the shoreline was subjected to recession of $31.78 \mathrm{~km}^{2} \pm 0.4 \mathrm{~km}^{2}$ and accretion of 20.67 $\mathrm{km}^{2} \pm 0.4 \mathrm{~km}^{2}$, which represent $60,6 \%$ of eroded areas against $39.4 \%$ of added new areas. Therefore, the local assessment of medium-term in shoreline trends shows an erosional setting in the Bragança coastal plain.

The decades shoreline recession during this 26 years period reached the maximum distances of about 1, $500 \mathrm{~m} \pm 28 \mathrm{~m}$ for the Maiaú Point, and $1,250 \mathrm{~m} \pm 28 \mathrm{~m}$ for the Buçucanga Beach, respectively (Figure 7A and 7B). These erosional settings represent the most seaward boundary of the coastal plain, which receive little or no muddy sediment. The main sedimentary process responsible for the shoreline retreat is related to sandflats migration landward over the mangrove. Mangrove vegetation has been killed by rapid sand deposition over it and mangrove terrace has been eroded. Hence, a significant sector of the shoreline encompassing, mainly, beaches, is characterized as transgressive deposits (Souza Filho and El-Robrini 1998). The shoreline accretion sectors are well represented by the Picanço Point, where the shoreline position has migrated around 1,250 $\mathrm{m} \pm 28 \mathrm{~m}$ seaward (Figure $7 \mathrm{C}$ ). In this area, the continuous sediment supply and the geomorphological position, protected from wave attacks, favor the accretion of sandbanks, muddy deposition and mangrove vegetation establishment. Migration of islands is observed along 
RADARSAT image (C) Canadian Space Agency, 1998

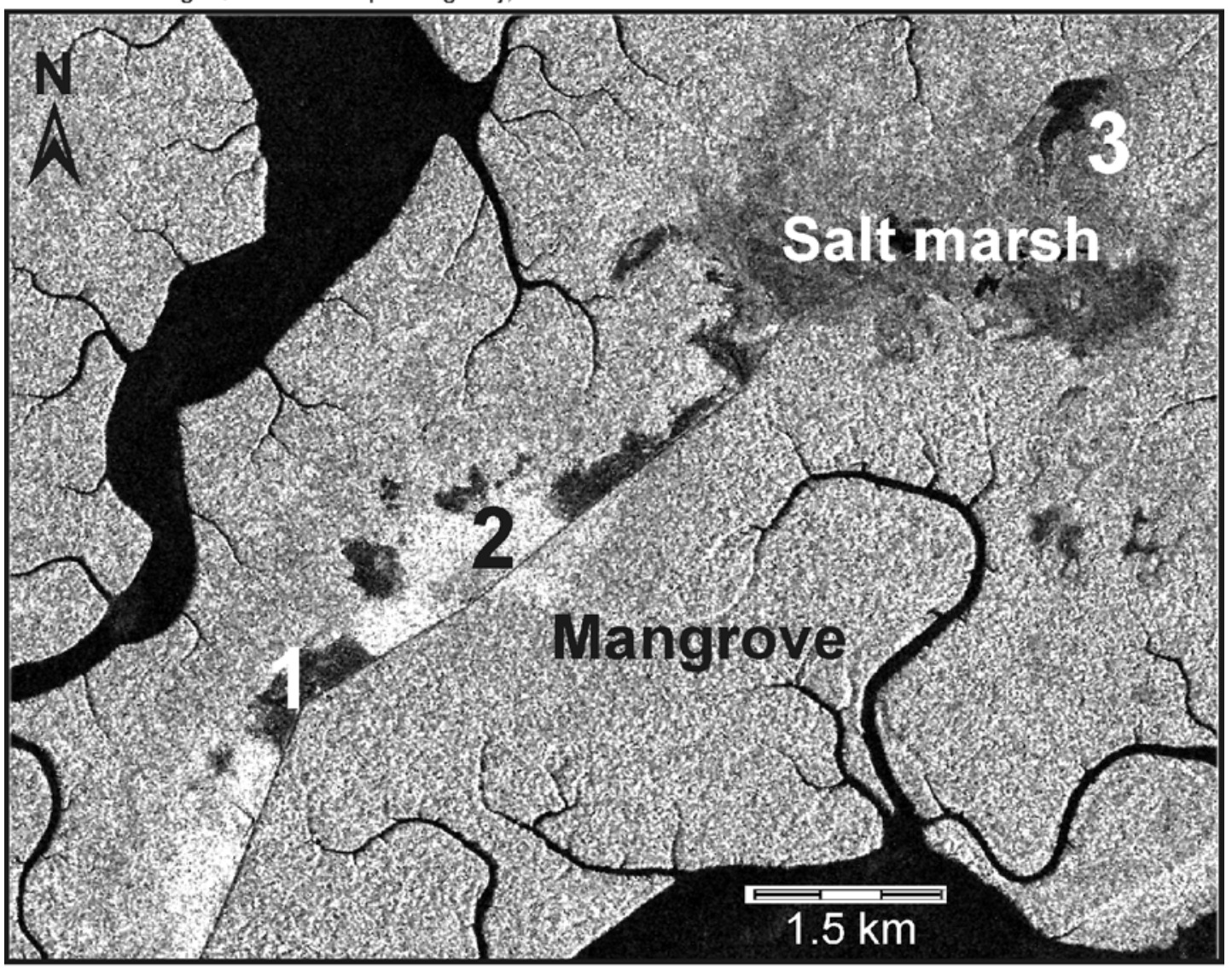

\section{1- Deforested mangrove} 2- Regenerated mangrove

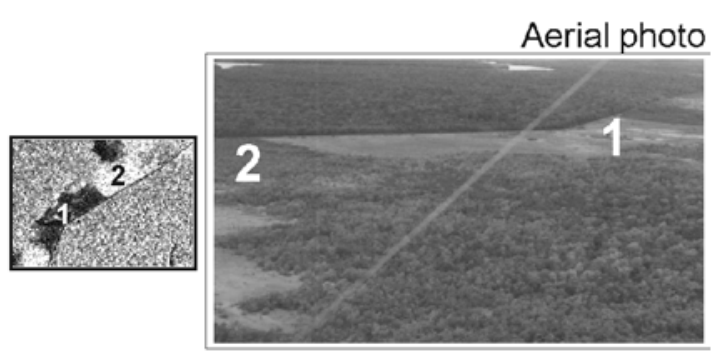

\section{3- Artificial lake}

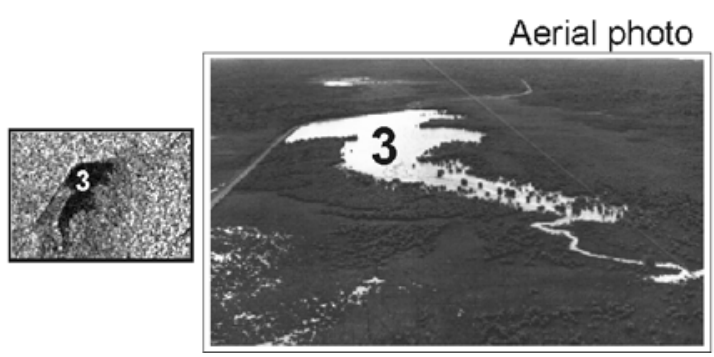

Fig. 5 - Land cover mapping from RADARSAT-1.

the Maiaú Bay in response to oceanographic and sedimentary processes. For example, the Maciel Island migrated almost $1 \mathrm{~km}$ from 1972 to 1998 (Figure 7C).

Previous authors have also addressed the mapping of coastal erosion in South America using SAR data. Singhroy (1996) reported changes in the shoreline along the Guyana coast, when comparing information extracted from 1992 airborne radar images and a 1972 topographic map. This comparison showed that part of the coast was subjected to severe erosion (maximum retreat about $500 \mathrm{~m}$ ), accre- 


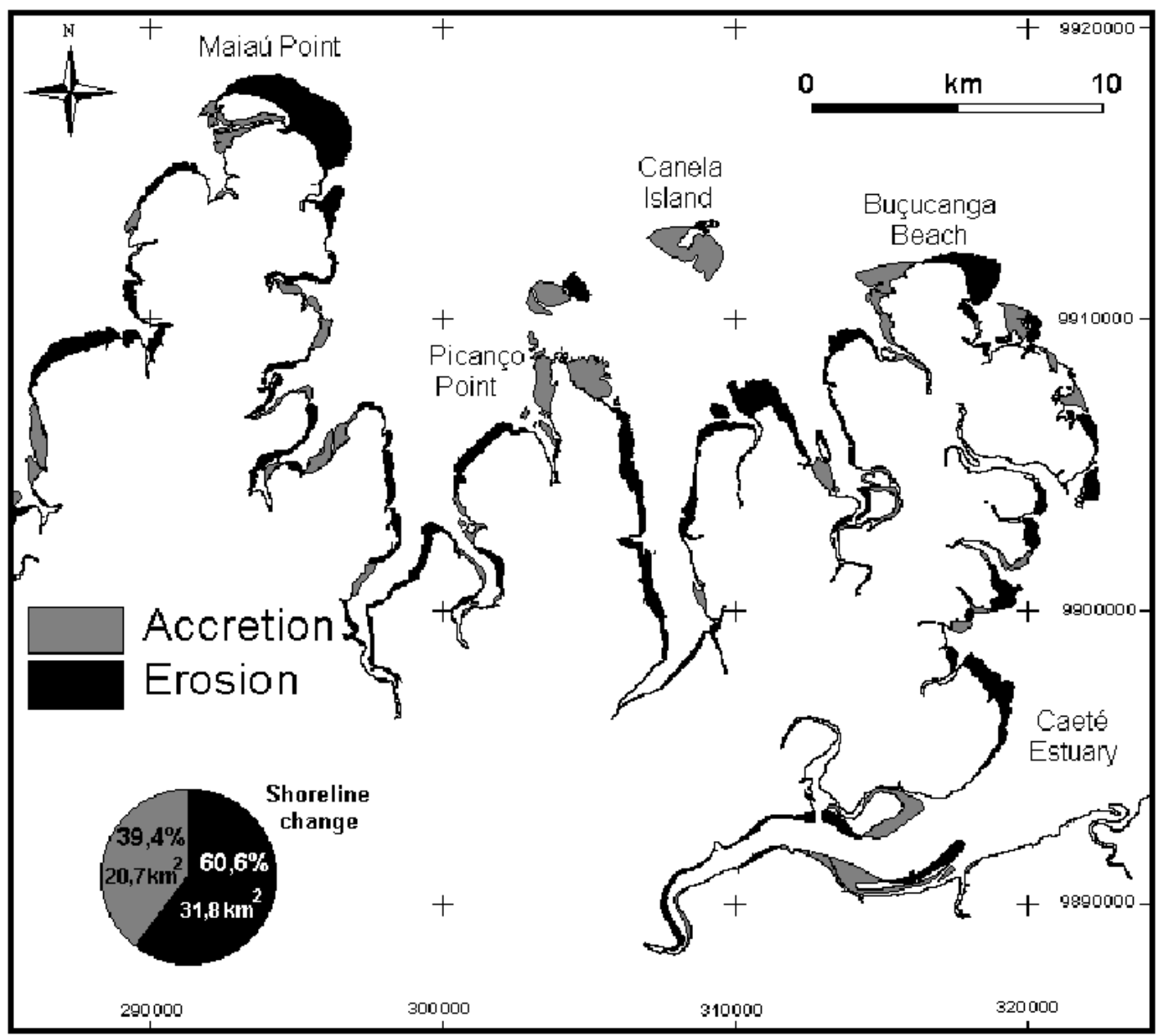

Fig. 6 - Vectors extracted from 1972 airborne GEMS 1000 SAR and 1998 spaceborne RADARSAT Fine Mode 1 showing shoreline changes in the Bragança coastal plain.

tion (maximum accretion about $500 \mathrm{~m}$ ) and stability associated to shoreline deposition-erosion cycle induced by mud bank migration (Rine and Ginsburg 1985). Based on a comparison from a 1996 RADARSAT-1 Standard Mode 7 scene and a 1971 topographic map, Barbosa et al. (1999) also concluded that the shoreline in the southern Paraíba coast (Northeastern Brazil) retreated between $150 \mathrm{~m}$ (resistant sandstone rocks) and $300 \mathrm{~m}$ (weak Quaternary deposits). This was associated to highly fractured areas, which increased the erodibility. The shoreline changes during the 26 years period (1972 to 1998) for the Bragança area reached up to 1,500 $\mathrm{m}$ of retreat and $1,250 \mathrm{~m}$ of accretion, while some parts remain unchanged. The causes of the dramatic shoreline changes in the Bragança coastal plain presented here are speculations due to the absence of wind, waves, and tidal currents data, but they need to be investigate in the future. However, according to Aubrey et al. (1988), the sea level trends in the northern Brazilian coast are closely linked with a structural low (Gorini and Bryan 1976, Souza Filho 2000a), which is responsible for continuing subsidence at a rate of $-0,3 \mathrm{~mm} /$ year at the city of Belém. This hypothesis is reinforced by the results presented by Souza Filho et al. (2003), which 
RADARSAT image (c) Canadian Space Agency, 1998
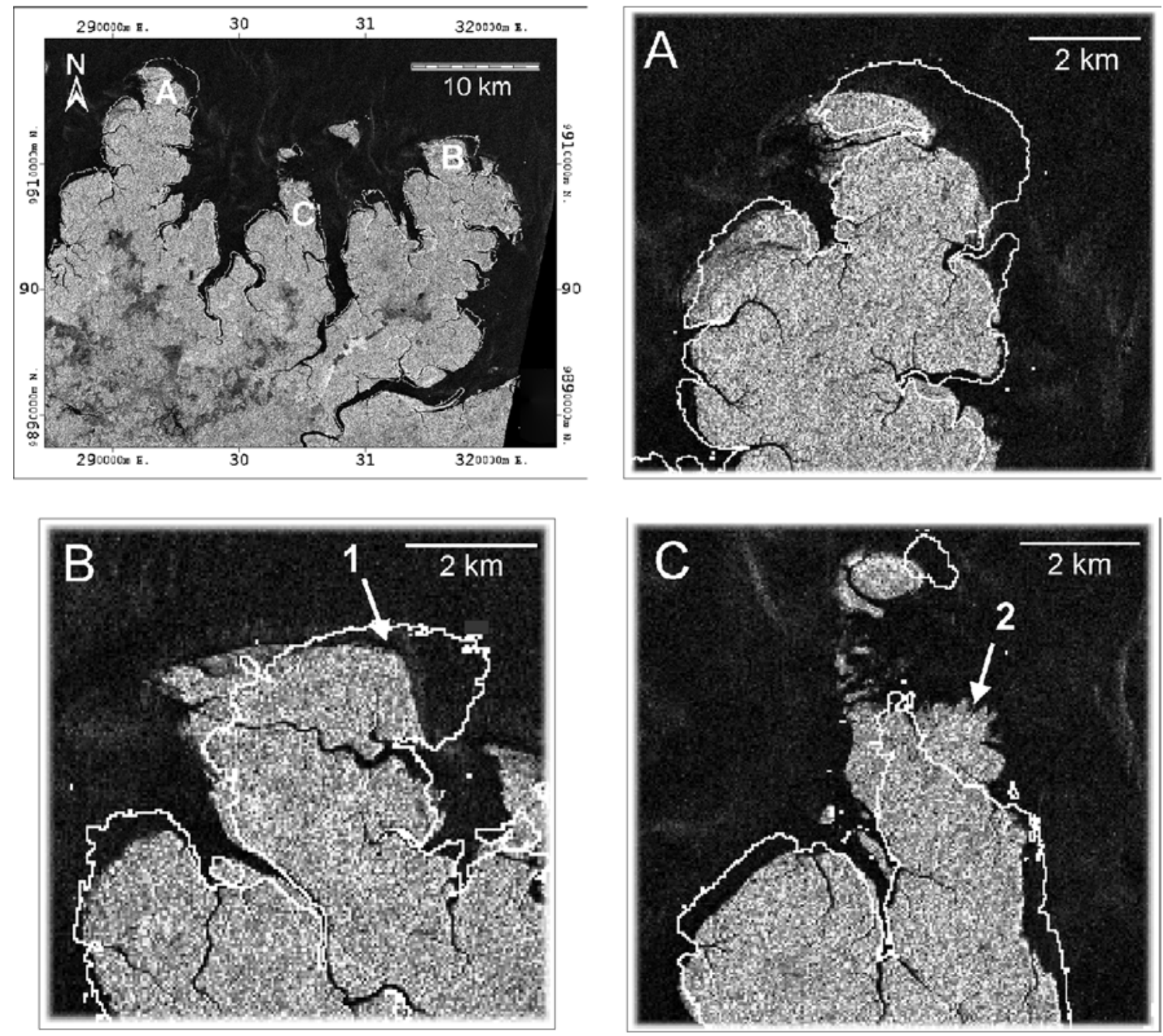

\section{1- Eroding mangrove shoreline}

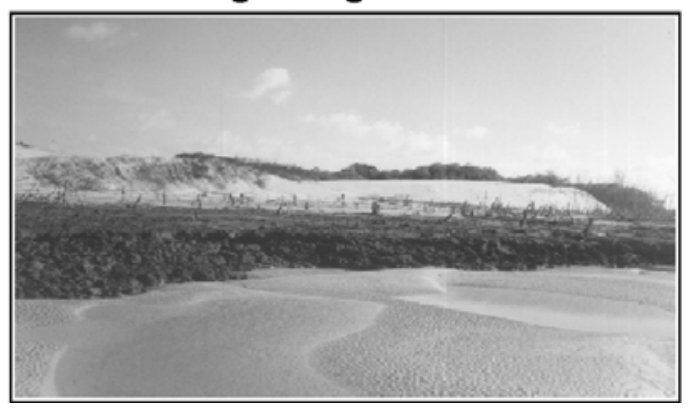

\section{2- Accreting mangrove shoreline}

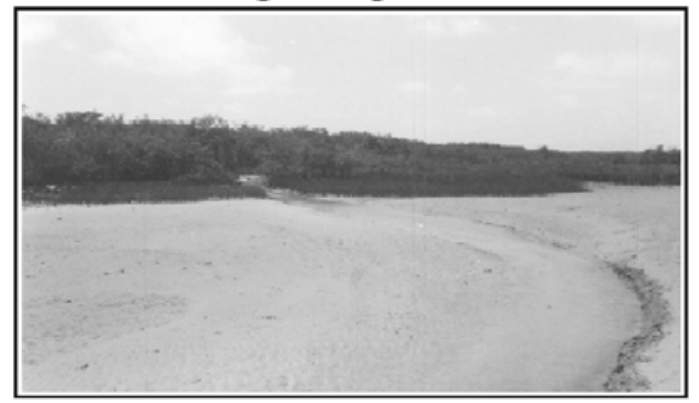

Fig. 7 - 1998 RADARSAT image and superimposed vector showing shoreline changes since 1972, coastal erosion and accretion, island migration and geomorphologic features. Maiaú Point (A) and Buçucanga Beach (B) erosional sector, and Picanço Point (C) accretionary sector showing an island migration process. 
show the shoreline retreat due to landward migration of sandflats and dune-barrier-beach ridge over mangrove deposits in response to tidal currents and wave action. These processes are responsible for development of transgressive sedimentary system, where marine environments are overlying intertidal deposits.

\section{CONCLUSIONS}

This paper has addressed the RADARSAT's capability to provide unique geomorphological and land cover mapping of the Bragança Coastal Plain. Furthermore, the integration of information provided by the orbital C-HH imagery with the airborne XHH SAR has allowed detecting and mapping coastal changes related to the shoreline retreat and accretion, during the 26 years period of both SAR acquisitions. Sedimentary dynamic, tidal current, wave action and estuarine and tidal channel displacements have played an important role in controlling these coastal changes.

Based on results obtained from SAR data analysis we can conclude that SAR imageries have provided valuable, rapid and accurate information on coastal features recognition, coastal land-use assessment, monitoring of shoreline changes and base maps updating, which are basic components for an integrated management program in this coastal zone. SAR data provides greater details of the coastal environments and configuration of the shoreline and its changes. The medium terms changes observed are mainly related to the interaction between macrotidal coastal processes and mangrove dynamics operating in the surrounding area, as well as the variations in estuaries discharges, sediment load and precipitation.

The use of microwave remote sensing is particularly relevant when considering the tremendous lack of information and the complexity of this fragile and sensitive moist tropical environment. The nature of the coastal dynamics related to winds, tides, waves and currents must be investigated and combined in the future to remote sensed data to explain how multitemporal series of SAR images can be used to generated a model of the spatial and temporal variation of coastal changes on a macrotidal mangrove coast in the Brazilian Amazon region.

\section{ACKNOWLEGMENTS}

The first author would like to thank the National Institute for Space Research (INPE) for the structural support for the digital image processing and the Federal University of Pará (UFPA) for the financial support for the fieldwork survey. Special thanks to Dr. Robert Laundry (CCRS) and the Canadian Space Agency for providing the RADARSAT- 1 image under the GlobeSAR-2 Program. Thanks are also extended to Dr. Maycira Costa (INPE) for helpful comments on the manuscript. The first and second authors would like to thank $\mathrm{CNPq}$ (Brazil) for research grants received (CNPq \# 303238/2002-0 and \# 300985/90-8, respectively).

\section{RESUMO}

Imagens de radar de abertura sintética (SAR) vem sendo bem mais utilizadas do que antes nas aplicações de geociências em regiões tropicais úmidas. Nesta investigação, uma imagem RADARSAT-1, na banda C, polarização HH adquirida em 1998 foi usada para o mapeamento costeiro e avaliação da cobertura da terra na área de Bragança, norte do Brasil. Imagem do radar aerotransportado GEMS-1000, na banda X, polarização $\mathrm{HH}$, adquirida em 1972 durante o projeto RADAM foi também utilizada para avaliar as variações costeiras ocorridas nas últimas três décadas. A pesquisa tem confirmado a utilidade da imagem RADARSAT-1 para o mapeamento geomorfológico e avaliação da cobertura da terra, particularmente em costas de manguezal de macromaré. Além disso, um novo método para estimar as variações da linha de costa baseado na superposição de vetores extraídos de diferentes imagens SAR, com alta acurácia geométrica, tem mostrado que a planície costeira de Bragança tem estado sujeita a severa erosão responsável pelo recuo de aproximadamente $32 \mathrm{~km}^{2}$ e acreção de $20 \mathrm{~km}^{2}$, resultando em uma perda de área de manguezal de aproximadamente $12 \mathrm{~km}^{2}$. Como perspectiva de aplicação, dados SAR orbitais e aerotransportados provaram ser uma importante fonte de infor- 
mação tanto para o mapeamento geomorfológico, quando para o monitoramento de modificações costeiras em ambientes tropicais úmidos.

Palavras-chave: geomorfologia, mudanças costeiras, sensoriamento remoto, manguezal, Amazonas.

\section{REFERENCES}

Aubrey DG, Emery KO And Uchupi E. 1988. Changing coastal levels of South America and the Caribbean region from tide-gauge records. Tectonophysics 154 : 269-284.

Behling H, Cohen MCL AND LARA RJ. 20001. Studies on Holocene mangrove ecosystem dynamics of the Bragança Peninsula in northeastern Pará, Brazil. Palaeogeograph, -climatology, -ecology 167: 225-242.

Barbosa MP, Singhroy V and Saint-Jean R. 1999. Mapping coastal erosion in Southern Paraíba, Brazil from RADARSAT-1. Can J Remote Sens 25: 323-328.

Cohen MCL, Lara RJ, Szlafstein CF and Dittmar T. 2000. Analysis of mangrove inundation by GIS techniques. In: Barros H. (ed.), Sustainability of estuaries and mangroves: challenges and prospects. Recife: UFRPE/ISME, p. 1-10.

Costa MPF, Niemann O, Novo EMLM, Ahern F and Mantovani JE. 2002. Biophysical properties and mapping of aquatic vegetation during the hydrological cycle of the Amazon floodplain using JERS-1 and RADARSAT. Int J Remote Sens 23: 1401-1426.

Crowell M, Leatherman SP and Buckley MK. 1991. Historical shoreline change: error analysis and mapping accuracy. J Coastal Res 7: 839-852.

DHN. 2000. Tábuas de Marés para 2000: Costa do Brasil e alguns portos estrangeiros. Rio de Janeiro: DHN, 200, p. 9-11.

Ellis JM AND Richmond DA. 1991. Mapping the Coastal Plain of the Congo with Airborne Digital Radar. Thematic Conf. on Geol. Remote Sensing, 8, 1991. Denver, USA. Proceedings... New York: ISPRS, 1991, p. 87-100.

Forsberg BR, Hashimoto Y, Rosenqvist A AND Miranda FP. 2000. Tectonic fault control of wetland distributions in the Central Amazon revealed by JERS-1 radar imagery. Quaternary Int 72: 61-66.
GorInI MA AND BRYAN GM. 1976. The tectonic fabric of the Equatorial Atlantic and adjoining continental margins: Gulf of Guinea to northeastern Brazil. An Acad Bras Cienc 48 (supl.): 101-119.

JoHANNESSEN JA. 2000. Coastal observing systems: the role of synthetic aperture radar. Johns Hopkins APL Tech. Digest. 21: 7-14.

Kjerfye B, Perillo GME, Gardner LR, Rine JM, Dias GTM AND MocheL FR. 2002. Morphodynamics of muddy environments along the Atlantic coasts of North and South America. In: HeAly TR ET AL. (Ed), Healy Muddy Coasts of the World: Processes, Deposits and Functions, Amserdam: Elsevier Science, p. 479-532.

Kushwaha SPS, Dwivedi RS and Rao BRM. 2000. Evaluating of various digital image processing techniques for detection of coastal wetlands using ERS-1 SAR data. Int J Remote Sens 21: 565-579.

Leconte R And Pultz TJ. 1991. Evaluations of the potential of RADARSAT for flood mapping using simulated satellite imagery. Can J Remote Sens 17: 241-249.

LeE JS AND Jurkevich B. 1990. Coastline Detection and Tracing in SAR Images. IEEE Trans Geosci Remote Sens 28: 662-668.

Lewis AJ, Henderson FM And Holcomb DW. 1998. Radar fundamentals: the geoscience perspective. In: Henderson FM And Lewis AJ. (Ed.), Principles \& Applications of Imaging Radar. Manual of Remote Sensing, $3^{\text {rd }}$ ed. New York: John Willey, p. 131-180.

Lopes A, Touzi R and Nezry E. 1990. Adaptive speckle filters and scene heterogeneity. IEEE Trans Geosci Remote Sens 28: 992-1000.

MacDonald HC, Lewis AJ and Wing RS. 1971. Mapping and Landform Analysis of Coastal Regions with Radar. Geol Soc Am Bull 82: 345-358.

Martorano LG, Perreira LC, Cézar EGM and PeReIRA ICB. 1993. Estudos Climáticos do Estado do Pará, Classificação Climática (Köppen) e Deficiência Hídrica (Thornthwhite, Mather). Belém: SUDAM/ EMBRAPA, 59p.

Moreira HF. 1973. Controle de qualidade de imagens de radar. Rio de Janeiro: Departamento Nacional de Produção Mineral (DNPM), 1973, 64p. Technical Report. 
Novo EMLM, Costa MPF and Mantovani JE. 1998. RADARSAT exploratory survey on macrophyte biophysical parameters in tropical reservoirs. Can J Remote Sens 24: 367-375.

Paradella WR, Krug T, Laundry R and Pietsch RW. 1997. GLOBESAR-2: O Programa de Avaliação de Dados do RADARSAT-1 nas Geociências. Rev Bras Geocienc 27: 403-406.

Paradella WR, Santos AR, Dall'Agnol R, Pietsch RW AND SAnt'Anna MV. 1998. A Geological Investigation Based on Airborne (SAREX) and Spaceborne (RADARSAT-1) SAR Integrated Products in the Central Serra dos Carajás Granite Area, Brazil. Can J Remote Sens 21: 376-392.

Paradella WR, Santos AR, Veneziani P and Morais MC. 2000. Synthetic Aperture Radar for Geological Applications in the Moist Tropics: Experiences from the Brazilian Amazon Region. Rev Bras Geocienc 30: 538-542.

PCI. 1999. EASI-PACE User's Manual, version 6.3. Ontario: PCI Enterprises, 282p.

Proisy C, Mougin E, Fromard F, and Karam MA. 2000. Interpretation of polarimetric radar signatures of mangrove forests. Remote Sens Environ 71: 56-66.

Projeto RADAM. 1973. Mapa Geomorfológico da Folha SA.23 São Luís e parte da Folha SA.24 Fortaleza. Rio de Janeiro: DNPM.

Rine JM And Ginsburg RN. 1985. Depositional facies of a mud shoreface in Suriname, South America: a mud analogue to sandy shallow-marine deposits. Jour Sed Petrol 55: 633-652.

Rosenqvist Å, Forsberg BR, Pimentel T, Rauste YA AND RICHEY JE. 2002. The use of spaceborne radar data to model inundation patterns and trace gas emissions in the central Amazon floodplain. Int J Remote Sens 23: 1303-1328.

SILVA MGL. 2001. Avaliação multitemporal da dinâmica costeira da praia do pescador, Bragança, Norte do Brasil. Master Dissertation, Universidade Federal do Pará (Centro de Geociências), Belém, Brazil. 113p.

SINGHROY V. 1996. Interpretation of SAR images for coastal zone mapping in Guyana. Can J Remote Sens 22: $317-328$
Singhroy V And SAINT-JEAN R. 1999. Effects of relief on the selection of RADARSAT-1 incidence angle for geological applications. Can J Remote Sens 25: 211-217.

Souza Filho PWM. 2000a. Tectonic control on the coastal zone geomorphology of the northeastern Pará State. Rev Bras Geocienc 30: 523-526.

Souza Filho PWM. 2000b. “Avaliação e aplicação de dados de sensores remotos no estudo de ambientes costeiros tropicais úmidos, Bragança, Norte do Brasil'’. Ph.D. Thesis, Universidade Federal do Pará (Centro de Geociências), Belém, Brazil. 219p.

Souza Filho PWM. 2001. Impactos naturais e antrópicos na Planície Costeira de Bragança. In: Prost MT ANd Mendes AC. (Ed.), Ecossitemas Costeiros: Impactos e Gestão Ambiental. Belém: MPEG, p.133-144.

Souza Filho PWM And El-Robrini M. 1996. Morfologia, processos de sedimentação e litofácies dos ambientes morfosedimentares da Planície Costeira Bragantina - Nordeste do Pará (Brasil). Geonomos 4: 1-16.

Souza Filho PWM and El-Robrini M. 1998. As variações do nível do mar e a estratigrafia de seqüências da Planície Costeira Bragantina - Nordeste do Pará, Brasil. Bol Mus Par Emílio Goeldi, Série Ciênc Terra 10: $45-78$.

Souza Filho PWM and El-Robrini M. 2000. Coastal Zone Geomorphology of the Bragança Area, Northeast of Amazon Region, Brazil. Rev Bras Geocienc 30: 518-522.

Souza Filho PWM and Paradella WR. 2002. Recognition of the main geobotanical features along the Bragança mangrove coast (Brazilian Amazon Region) from Landsat TM and RADARSAT-1 data. Wetl Ecol Manag 10: 123-132.

Souza Filho PWM, Tozzi HAM and El-Robrini M. 2003. Geomorphology, land-use and environmental hazard in Ajuruteua macrotidal sandy beach, northeastern, Pará, Brazil. In: KLEIN ET AL. (Ed), Brazilian Sandy Beaches: Morphodinamic, Ecology, Uses, Hazards and Management. J Coastal Res, Special Issue, 35 (in press). 